\title{
MODELO EXPLORATÓRIO PARA DEPÓSITOS DE CHUMBO E ZINCO NA FAIXA ITAIACOCA-PR/SP \\ RODOILTON STEVANATO*
}

\author{
DISSERTAÇÃO DE MESTRADO - Programa de Pós-Graduação em Geologia - UFPR \\ DATA DE DEFESA: 06/11/98
}

Neste estudo, procurou-se aplicar e interrelacionar três grandes áreas do conhecimento: a geologia, a geoquímica e a geofísica voltadas para a elaboração de um modelo exploratório para depósitos de chumbo e zinco do tipo Mississippi Valley ou Irlandês, em ambiente modificado por processos tectono-metamórficos de idade meso/neoproterozóica, na Faixa Itaiacoca, inserida no escudo leste paranaense. Inicialmente, discorre-se um breve histórico do estado da arte na exploração mineral, cujo desenvolvimento é apoiado em técnicas prospectivas e na sua condução à elaboração de programas exploratórios. Tais programas, simples e eficazes, devem estar direcionados ao objeto, ou seja, o depósito mineral. Geologicamente, os estudos foram centrados na área de Palmeirinha, município de Sengés-PR, junto à divisa dos estados do Paraná e São Paulo, dentro da Faixa Itaiacoca, situada a NNE do Complexo Batolítico de Cunhaporanga e na borda leste da Bacia do Paraná. As várias unidades mapeadas foram agrupadas de acordo com seu conteúdo litológico, características primárias, metamorfismo e deformações associadas. Individualizaram-se três complexos tectono-metamórficos e uma unidade granítica denominada Granito, São Domingos. A unidade portadora, potencialmente favorável ao depósito de chumbo e zinco aqui estudado, é representada por espessa seção de metapelitos e metacalcários intensamente deformados ao longo da direção NS, incorporando feições dúcteis e rúpteis, em sistemas de cavalgamentos, empurrões, falhamentos e dobramentos, com metamorfismo na fácies xisto verde inferior. A mineralização descoberta ocorre na porção basal da unidade metapelito-carbonática, em zona de falha transcorrente com direção N10E, subvertical e com rejeito lateral, causando cataclase e brechação nas encaixantes e nos metais-base. A mineralização hospeda-se em metadolarenitos intercalados por cálcio filonitos carbonosos e xistos quartzo-feldspáticos adjacentes. $O$ minério compreende disseminações de galena e esfalerita com pirita e raros cristais de calcopirita, marcassita e covelita, os quais distribuem-se em fraturas e na matriz de brechas com remobilização e recristalização. As técnicas empregadas para a descoberta do depósito, incluem perfis de solos perpendiculares à direção das camadas e foram locados em função do conhecimento geológico prévio, ocorrências minerais, presença de gossans, estruturas e interface metapelitos/metacalcários; os alvos definidos foram escavados por trincheiras e perfurados, os quais resultaram na descoberta do depósito com teor de 7,0\% de $\mathrm{Pb}$ e 3,0\% de $\mathrm{Zn}$ com espessura de 1,30 metros. A geofísica, particularmente os métodos magnético e gamaespectrométrico (aéreos e terrestres), auxiliaram o mapeamento geológico/estrutural, enquanto os métodos IP/resistividade detectaram as continuidades vertical e lateral da mineralização, as quais foram confirmadas por novos furos exploratórios. A principal contribuição do presente estudo é a proposta de um modelo exploratório para depósitos de chumbo e zinco em metadolarenitos, enfocando desde a escala do contexto geotectônico até à microscopia da mineralização, além das técnicas e estratégias mais importantes na busca de novos depósitos de metais-base na Faixa Itaiacoca.

*E-mail: rodo@setuva.geologia.ufpr.br 